\title{
Obituaries
}

\section{Harold R. Isaacs (1910-86)}

Harold R. Isaacs died on 9 July 1986 in the Massachusetts General Hospital, a week and a day after open heart surgery. He was a major figure as an actor in and chronicler of the China scene, and as both a journalist and a scholar-analyst of world affairs. He left us with much more than "scratches on our minds" - he left us with deep, indelible impressions of a truly exceptional and spirited man who had a remarkably adventuresome life.

First there was New York City and Columbia University, where Harold had his beginnings as a journalist, reporting for the New York Times on Protestant church sermons - for which he was paid $\$ 3.25$ each Sunday, $\$ 3.00$ in wages, 10 cents for the subway and 15 cents for the collection plate. Then it was off to Shanghai to be caught up in the turmoil of the labyrinthian politics of Chinese intellectuals of the left. There he boldly founded and edited the China Forum, a publication which became a vehicle for the tormented articulations of progressive writers. He associated with such illustrious figures as Lu Xun, China's greatest modern author, Song Ching-ling, Sun Yat-sen's widow, whom he knew fondly as Suzie, and the later-to-be-famous, Ho Chi Minh.

With Song Ching-ling, Lu Xun, Cai Yuanpei, Yang Qian and Agnes Smedley, Isaacs founded the China League for Civil Rights to expose the Kuomintang's mistreatment of writers. In time, however, the League was taken over by the Stalinists in the Chinese Communist Party as their front group. Isaacs with the help of Lu Xun and Mao Dun selected some of the best writings from the China Forum in the expectation that the collection would be published in New York, but by the time the manuscript was completed, with Lu Xun's preface, none of the leftist publishers would accept a work associated with an "enemy of the people" as identified by Moscow. Straw Sandals lay in Isaacs's files forgotten until he rediscovered and published it in 1974.

When, after two years the Forum had to close down because of the irreconcilable conflict between Harold's idealistic principles and the Communists' rubbery changes of "line," he went on to Beijing and to a phase of withdrawal from activism as he toiled to make his mark as a scholar-author by writing his great work The Tragedy of the Chinese Revolution. There were then the years, first as a journalist with Agence France Presse and then, as war came to Europe as well as Asia, he became a script writer for the CBS Radio programme, Report to the Nation, which featured an imperious Orson Welles. He soon found that dealing with such an irascible egotist and the trivial quarrels of the executive suite were intolerable, especially at a time of momentous world events, and he happily signed on at Newsweek as war correspondent for Chungking, New Delhi and Mountbatten's head- 
quarters in Ceylon. Then came tours as a roving observer of the end of the colonial rule in South-east Asia and of the American liberation of South Korea. His findings were put together in a disturbingly prophetic book, No Peace for Asia. All of this before his academic years in Cambridge.

From the moment Harold Isaacs joined the Center for International Studies in 1953, and thereby began his second career as an academic, he became a vital force in provoking intellectual curiosity about urgent, "real-world" problems among a band of colleagues who were often more absorbed with spinning out their own worlds of theoretical abstractions. Coming late to academic life, he was never intimidated by the verbiage of the social sciences. Indeed, Harold had a lasting pride in his identity as a one-time journalist, and he was always slightly amused at finding himself a professor. He had a keen eye for the foibles of academia and enjoyed quoting C. P. Snow's definition of a university as a place "where men indulge themselves by bestowing honours upon each other." Harold was able to preserve such a bemused feeling for academia because he kept enough distance to avoid learning about academic administrative politics. He was finally trapped into becoming a full-status, full professor by the ingenious but questionable administrative ruling that he could only be given a parking sticker if he became a bona fide faculty member. With that status Isaacs soon became both a lively role model for students and a sympathetic listener to those with personal problems. He had an extraordinary ability to keep a compassionate heart when patiently listening to, and at times aggressively probing into, such problem cases but then coming up with hard-headed prescriptions for solutions.

In carrying out the research for his first MIT book-Scratches on Our Minds, called a "classic" by the New York Times-Harold, in probing interviews, peeled back layer after layer of the memories of American opinion makers to get at the deeply buried images they held of Chinese and Indians. That study of the importance of unconsciously held predispositions of influential Americans convinced Harold once and for all that the personal, human factor was far more important in shaping history than the class categories he had once used. Consequently, he turned his considerable energies to exploring the critical role of changing group identities in contemporary world politics. On a two-year trip for the Center for International Studies, accompanied by his wife and supportive critic, Viola, he collected material for a series of studies on the attitudes of American blacks towards Africa, of American Jews living in Israel, of Untouchables in a changing India, English-educated Chinese in Malaysia, Filipinos emerging from American colonial rule, and of generational changes in Japan. His first-hand studies were subsequently enriched by extensive book-learning to produce his wide ranging and profoundly throughtful book, The Idols of the Tribe, which still stands as the pioneering work of the now popular field of ethnic studies. As he observed in that 
work, "The evidence of current human affairs seems to suggest that the House of Muumbi is where man really lives, that his essential tribalism is so deeply rooted in the conditions of his existence that it will keep cropping out of whatever is laid over it, like trees forcing their way through rocks on mountain sides a mile high."

Harold Isaacs's career progressions might suggest a restless person in search of himself, but this most certainly was not the case. He was, rather, a man of singularly firm and unambiguous self-identity. His values were such that he always knew where he stood even while he explored with infinite care and sympathy the shifting uncertainties and psychic problems of people experiencing dramatic changes in their own sense of group identity. Harold had a powerful, vivid personality of extraordinary consistency. How he maintained the clarity of his attitudes and values was something of a mystery, for he was also a person possessed of exceptionally strong emotions which in someone of lesser character would have produced vacillation, contradiction and ambiguity.

Even more puzzling was that Harold Isaacs lived daily with intense inner tensions between the clashing emotions of anger and loveanger at the wrongs he unfailingly found in the public affairs of the world, and love in the form of a profound compassion for all who were a part of his private world. Harold had a compelling need to shout at fools, to vent rage at the follies of leaders who were, in his view, if not bringing our world to disaster, were making it a worse place than it could and should be. He was addicted to the news, even though what he read and saw caused him almost daily anguish.

Harold's powerful emotions must have been a major factor in shaping his fundamental career identity, that of a writer and author. He undoubtedly came to his calling as a writer the hard way, by forcing himself to discipline what could have been unruly outbursts of feelings. The agony of that disciplining process was, no doubt, learned as Harold struggled in the solitude of Beijing to write his great work, The Tragedy of the Chinese Revolution, in which he told in clear, precise, unvarnished prose the story of what he saw as two abominations, the Stalinists of the Communist Chinese Party and the thugs in the Kuomintang. In doing so, he practised Wordsworth's definition of poetry as "strong emotions reflected in tranquillity."

In the years at MIT Harold was usually hunched over his typewriter, pecking out words with the journalist's two fingers, filling yellow pages with crossed-out words and scribbled, untidy revisions. But there was nothing casual about what he had done, as anyone so bold as to try to alter even one word would discover, for he was the consummate craftsman who worked tirelessly to find the precise words for what he had to say. He found the idea of copy-editors abhorrent, for as he repeatedly noted, "Who would think of touching up a Rubens or even a Jackson Pollock, or add some notes to Beethoven or Mozart? So why is it acceptable to tinker with another person's literary creation." The only person Harold accepted as an 
appropriate and qualified critic was Viola, and even with her there could be something of a battle. On the last day of his life a young doctor came in to see him and cheerfully said, "You look great," to which Harold responded, "Young man, I have always tried to find the right word for whatever needs saying, and I am sure on this occasion 'great' is not the right word."

Harold's reverence for language involved more than just the pride of the master craftsman, it was sustained by his frequently expressed belief that all serious writing is to some degree autobiographical, embodying an element of the identity of the author. Whatever truth his theory might have for others, it certainly was manifest in his last, and very moving book, Re-Encounters in China, in which a mature and very wise Harold Isaacs, with considerable bemusement, reflected on not only the pathetic fates of his one-time Chinese friends but also on his own youthful audacity in believing that Marxism-Leninism could be reconciled with honesty and justice.

Right alongside his fury at the state of the times was Harold's other contending passion, an outpouring of compassion and love for all those he embraced as his family. "Family" for him started with his immediate loved ones but quickly reached out to include that extraordinary network he called his "extended family." Isaacs invested tremendous amounts of energy and care in maintaining a wide range of friendships from every phase of his career, but he always held in special regard his Asian associations, and more particularly those who shared with him a China dimension.

The contrast between the youthful Harold Isaacs who was ready to change the world and the mature Harold Isaacs who attached supreme importance to the most private matters of personal identity and the bonds of friendship might suggest a person who had retreated from the world in disillusionment. Particularly since he also became a person given to moments of cantankerous derision of the vanities of public figures. This, however, would not be a correct reading of Isaacs's transformations, for in a very fundamental way he remained an idealist; it was only that his focus of concern had shifted from abstractions to concrete individuals. Isaacs continued to be a romantic; no longer in political terms but by clinging to an idealized vision of what direct human relationships can be.

As a result of this transformation, Isaacs became increasingly impatient with the thought that political considerations should rule personal relationships. He was thus both bemused and exasperated that his Shanghai days' friends would have nothing to do with him until the Beijing authorities declared him no longer pollution, but then when they finally met in his re-encounters it was as in a time capsule, for the Chinese sought to blank out all that had happened between those Shanghai days and Deng's reforms. We can hope that the current, new relations between Chinese and foreigners will follow Harold Isaacs's pioneering pattern, and that political impetus for 
association will prove to be secondary to the integrity of enduring personal relations.

Although Harold Isaacs clung to his self-identity as a journalist, his enduring contributions will be in the realm of scholarship. First, for the meticulous historical reconstruction of devious and sordid events in the Chinese revolution, and second for his sensitive analysis of how people in a changing world have struggled to develop and maintain acceptable feelings of group identity. As an analyst of modern nationalism, especially among the emerging nations of Asia and Africa, he moved directly to the heart of world affairs thereby reminding all students of Chinese developments that such concerns are the essence of modern world history.

LUCIAN W. PYE

\section{Werner Klatt (1904-87)}

Dr Werner Klatt, OBE, died on 21 January 1987, at his home in London, aged eighty-two. He had been closely associated with The China Quarterly since its foundation, as a member of the Editorial Board (until 1984) and as a frequent contributor. When he resigned from the Board he was made an honorary member of the Quarterly in recognition of his outstanding service to the journal.

Dr Klatt had a colourful, varied career. He was born in Berlin in 1904, and it was at the University of Berlin that he spent several years studying agriculture, taking a doctorate in 1930 . He followed this with three years' research in agricultural economics, under Professor Karl Brandt, who later moved to Stanford University. During the 1930s he worked in Berlin in the field of agricultural marketing and as an adviser to I. G. Farben.

When the war broke out, he and his wife took refuge in England, and throughout the war Dr Klatt was employed by the British Government as an expert on European food and agriculture. In the early post-war years he was involved in making food and agricultural projections for Europe, and especially for Germany. From 1946 to 1949 he was in charge of the Supply Department of the German Section in the Foreign Office. From 1951 to 1966 he was an economic adviser to the Foreign Office in London, working on both Europe and China, with an increasing emphasis on the latter. He retired from the Foreign Office in 1966, and thereafter he was associated with St Antony's College, Oxford, and with the Contemporary China Institute at the School of Oriental and African Studies.

Dr Klatt knew a great deal about the theoretical and practical aspects of agriculture, and he was proud of his experience as a farm manager. His scientific background, together with a deep understanding of economics, enabled him to make some sound judgments about the potential of Chinese agriculture and also about its current performance. His work was analytically interesting, but as time went 
on, it became empirically limited because of his lack of access to Chinese-language materials. However, he produced many thoughtprovoking studies - mostly pessimistic - at a time when many scholars who had more specialized training were writing unjustifiably optimistic commentaries on China's agricultural performance.

The private visit he made to China in the early 1980 s did nothing to increase his enthusiasm about the possibility of Chinese agriculture becoming either modern or efficient. Unfortunately, he stopped writing at the time when the collectives were disbanded, and he did not live long enough to be able to see the long-term effect of this dramatic reform.

Werner Klatt had a towering, overwhelming personality and a keen intellect, which made him both engaging and at the same time something of a challenge as a colleague. He was a warm, loyal friend, totally free with his invaluable advice and extraordinary knowledge. Those, like myself, who for many years enjoyed his friendship and received a great deal of encouragement and help from him, are very conscious that his death deprives us, and the field of Chinese economic studies, of an outstanding colleague and a great personality.

KENNETH R. WALKER

\section{Murray Mindlin (1924-1987)}

Murray Mindlin was associated in two capacities with The China Quarterly from 1982 until his untimely death on 8 May 1987. He worked as acting assistant editor from January to end September 1982. When the assistant editor returned, he was given responsibility for increasing the advertising revenue and promoting the circulation of the journal. He was working in this capacity when he suffered the illness which led to his death.

Drawing on a lifetime's experience in publishing and his own remarkable scholarly attributes, he made a major contribution to the production of the journal throughout the period of his active association with it. When his term as acting assistant editor was completed, it was evident that he had so much to give that he was offered the role of promoting the journal and enhancing its position as the principal professional medium for advertising books in the field of modern Chinese studies.

By profession, a publisher, he was also a scholar with an international reputation in Assyriology. In this field his writings included Reflections of Gudea (forthcoming), and he edited jointly with Dr M. J. Geller and Professor J. E. Wansbrough a volume of papers, Figurative Language in the Ancient Near East, to be published late in 1987 by the School of Oriental and African Studies.

Outwardly, Murray Mindlin was a gentle and humorous person, yet he had a strong inward sense of the need for justice and human rights to which he devoted a not inconsiderable part of his professional 
life. His early death inevitably leaves gaps both personal and professional.

Our sympathies are extended to his wife and family. His expertise and friendship will be sadly missed in this office.

BRIAN HOOK 